\title{
The Effectiveness of The Cooperation and Coordination of Stakeholders in The Management Area Upstream Watershed Brantas
}

\author{
Tri Sulistyaningsih ${ }^{1}$, Masduki ${ }^{2}$, Salahudin $^{3}$ \\ \{ sulis226@gmail.com ${ }^{1}$ \} \\ Universitas Muhammadiyah Malang ${ }^{1,2,3}$
}

\begin{abstract}
This article aims to describe the cooperation and coordination of stakeholders in the management of the area upstream Watershed Brantas. Through a qualitative approach, the research revealed that the cooperation and coordination of stakeholders cannot run effectively caused by perception and understanding among the different stakeholders. Understanding differences caused the difference in capacity and powers that possessed each of the stakeholders. However, the stakeholders working to do conservation and maintain the sustainability of the Watershed areas through a participatory action approach Brantas.
\end{abstract}

Keywords: Cooperation, coordination, DAS Brantas, perception, understanding and conservation.

\section{Introduction}

DAS Brantas has potential and a very convenient function for the filmed East Java region. Unfortunately, the management potential of DAS Brantas has not been carried out seriously, quite the contrary, there is environmental damage in the WATERSHED upstream Brantas widespread impact on dwindling sources of water, drought in the dry season and floods in the rainy season [1]-[2]. Indications of damage of them i.e. eradicating Brantas WATERSHED number of springs in the upper areas of the region in the five mountains from which Brantas i.e. g. Arjuno-Welirang, G Kelud, g. Kawi Wilis, g. and g. spring contained in the Stone town had dried up. 11 Springs dry up while 46 springs discharge has decreased from $10 \mathrm{~m} 3 / \mathrm{sec}$ to less than $5 \mathrm{~m} 3 / \mathrm{sec}$. If there were no improvements to the management of the Brantas is good in the year 2020 East Java will have deficit water [3]-[4].

Water resources decline occurred in various cities in Indonesia even the world. This is caused by environmental pollution caused by direct human action which is not friendly toward the environment especially towards the River as water resources area. In the research result Herlambang, shows that the damage and decreased water resources continue to happen and getting worse. The current water pollution occurs virtually throughout the major cities of the world and already running for hundreds of years. These problems indicate that the underestimate environmental pollution damage to the environment is a matter of grave concern [5].

Later, Mawardi, i. (2011) specifically doing research on damage and inquiries area upstream WATERSHED Brantas. In the results of his research, Mawardi, revealed that most 
of the Watershed (DAS) on the island of Java, his condition had suffered damage and inquiries. It can be seen from the widespread closure of beverage land in the WATERSHED is only reaching less than $20 \%$, fluctuation a very large river discharge and the rate of erosion, sedimentation and water River destroyer which is quite high. Therefore, according to Mawardi, damage and inquiries that greatly affects the WATERSHED resource water resources carrying capacity in Java. Charge indicators will ever increase the frequency of flooding, landslides, and drought affecting the availability of the community which can be utilized [6].

One of the causes of damage and the WATERSHED upstream inquiries Brantas is the change in land use due to the increasing population in urban areas resulting in changes in land use are open into the settlement. The city community was not getting a decent place to move into open areas such as in the area of the Watershed upstream Brantas. Later, the area of settlement has led to a decrease in the quality of water in DAS Brantas. The other cause is a large number of pollutants originating from domestic waste, agricultural waste, waste, waste theme park market, hospital waste, and industrial waste that is dumped in the area upstream Watershed Brantas [7]. P, s. m., \& Suradisastra, kin the results of their study indicate that damage upstream due to the wild agriculture area or deforestation for agricultural purposes or exploitation of forest products. Destruction of forests is not only caused by the growing number of poor residents, but it can also be caused by the more sweeping rights forest management as well as investors who enter the territory inland [8].

Basically, the Government of Indonesia has sought to cope with the environmental pollution in the area upstream WATERSHED Brantas. For example, the research results a sham, a.) shows there are Government's efforts in improving the management of dry land in watersheds (DAS) the upper reaches has been done through various projects. According to Sham, the project aims to increase the productivity of land and the income of farmers, as well as to encourage the participation of farmers in the conservation of soil and water resources. In the results of the research of the Sham suggest that the system of farmer conservation terrace and patio bench can improve the productivity of farmer and farmer income, and can decrease the rate of erosion [1]. In line with the results of such research, Sulistyaningsih in the results of his research also shows that upright plant conservation can provide a welfare society by assuming the plants are productive and can be used economically [4].

Despite the Government's efforts have a positive impact against the conservation of the area upstream WATERSHED Brantas but there are other issues that should be examined further i.e. cooperation between stakeholders in the management of the area upstream WATERSHED Brantas which can provide the contribution to the economic growth of the community. So far, researchers have not been reviewed in depth about cooperation between stakeholders in the planning and supervision of the conservation area upstream WATERSHED Brantas when one of the sources of the problems of bad governance DAS Brantas is the absence of cooperation in the form of the excellent coordination between stakeholders in the management of DAS Brantas.

Also, the same understanding between government agencies and the community about the management area of the WATERSHED is not yet woken up correctly so that the WATERSHED area of governance cannot be done effectively. Sulistyaningsih in his research revealed that the understanding of stakeholders towards the sustainability of the WATERSHED is relatively high. But due to the political interests of the attraction power of stakeholders government often less concerned. On the other hand the community stakeholders i.e. they understand also about the need for preservation of the DAS, but the economic interests of a moment that resulted in less care with planting plants upright as a 
WATERSHED area of damage conservation efforts. This article examines cooperation between stakeholders in the management of the area upstream WATERSHED Brantas which focused on stakeholder networking in support of the conservation of the area upstream WATERSHED Brantas [4].

\section{Method}

This study used a qualitative approach by utilizing the methods of collecting data through observation directly to the location of research and in-depth interviews with local government and communities. Prior to observation, the key informant contacted investigators from Focal Mesra (Water and environmental Study Forum Towards Harmonised nature), Society of the village forest (LMDH), driving Water Rescue Partnership national movement (GNKPA), and the National movement of forest and land Rehabilitation (GNRHL).

In addition, to get the information in a more focused and in-depth, this research method using Focus Group Discussion (FGD) with Government stakeholders stone town and a group Farmers Matter DAS Brantas, and among the academic environment. Thus the sample was chosen by purposive against those who have characteristics i.e. those involved in the development of the WATERSHED upstream Brantas as both Governments, farmer groups, and NGOs. As for the secondary data collected through good documentation, techniques comes from the Government or documentation search results done by the community. The data analysis was done in the task of qualitative.

This research was conducted in the village of Sumberbrantas. Sumberbrantas village is a Village that lies southwest of the relic in the slopes of Mount Arjuno which is a mountainous area and has a stretch of farmland that provides welfare for the people of the village of Sumberbrantas. The villagers Sumberbrantas almost in its entirety is a farmer who produces agricultural products generally vegetables and horticulture. In the village Sumberbrantas, there is a wellspring of Brantas River that flows to some areas of East Java [7].

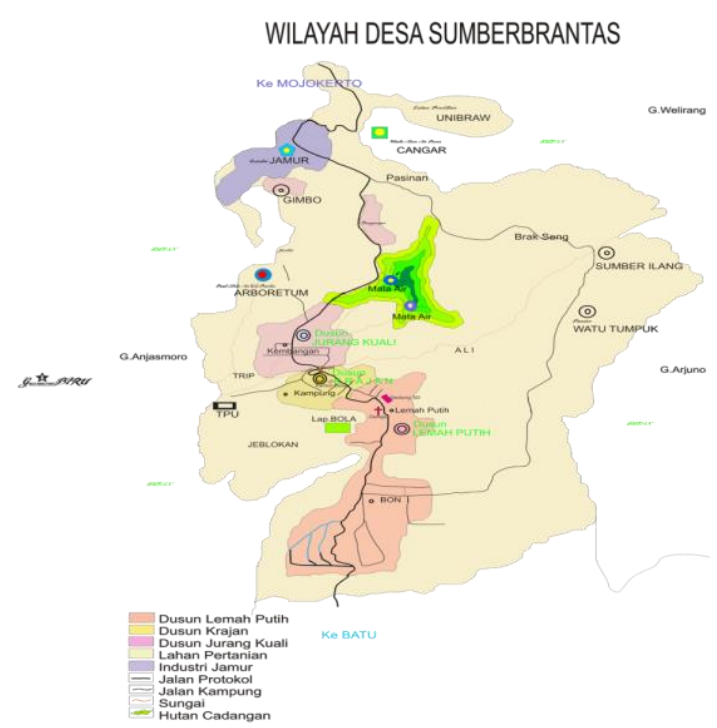

Figure 1. Map Of The Village Of Sumberbrantas Town Of Stone

DAS Brantas is located in East Java region, has a length of $320 \mathrm{~km}$ and has an area of $12,000 \mathrm{~km} 2$ WATERSHED covers approximately $25 \%$ of the land area of the province of East 
Java. Some of them traveled County town of Batu, Blitar, Malang, Tulung Agung and Surabaya. The position of the DAS is on the Brantas $110^{\circ} 30^{\circ} \mathrm{E}$ to $112^{\circ} 55^{\prime} 15^{\prime \prime} \mathrm{n}$ BT and $7^{\circ}$ $01^{\circ}$ LS samp ai $8^{\circ} 15^{\circ}$ LS. That means about the more extensive quarter of East Java province. (Figure 1.1).

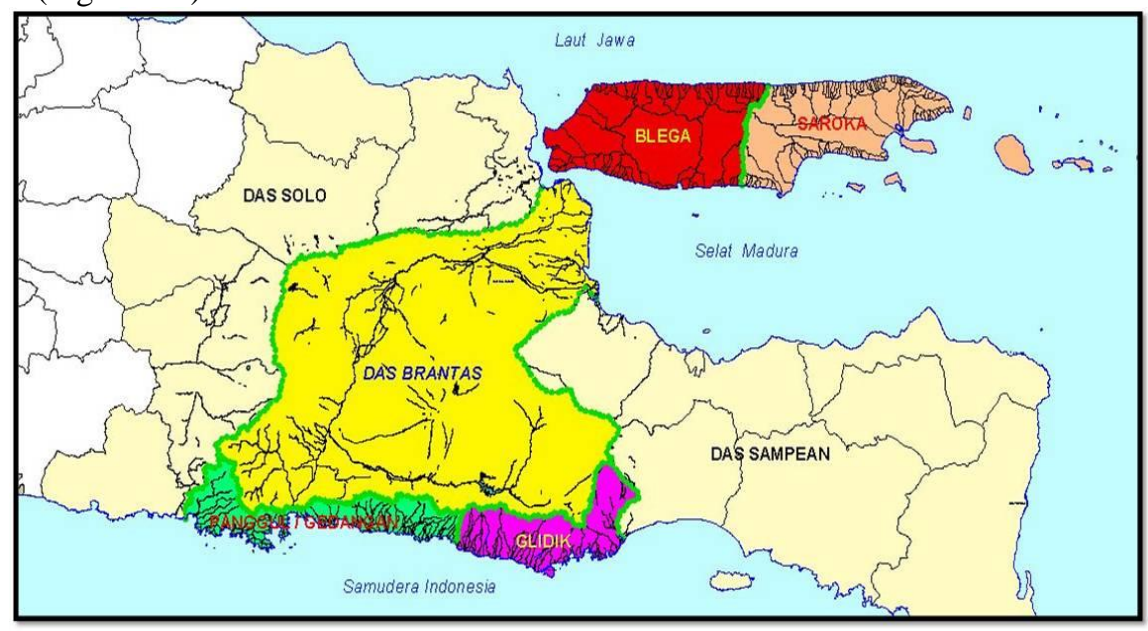

Figure 2 Map DAS Brantas

DAS is an area or region with varied slopes slope bounded by the Ridge-Hill or mountain, which can accommodate year-round rainfall where water accumulated in the main river which flowed steadily towards the sea, so it is an ecosystem of water governance area [9] Similar with the opinion Sarief, Dunne and Leopold, 1978 defines the watershed (DAS) as the expanse of the area bounded by topographic delimiters (Ridge) that receive, collect rainwater, sediment, and nutrient elements and flow through the creeks and out at one point (the outlet).

While according to Asdak WATERSHED ecosystems is usually divided into upper, middle, and lower. Upper area is an area of conservation, has a higher drainage density, with slope slopes greater than $15 \%$, not the flood area, the settings are determined by the use of water drainage patterns, and type of vegetation is generally the stands of forest. While the lower area of the WATERSHED is the area of the utilization with a small slope (slope less than $8 \%$ ), in some places is a flood area, the use of water is determined by the setting of the building of irrigation, and the type of vegetation is dominated by plants Agriculture except for the estuary of the dominated area of peat forest/mangrove. DAS is the central part of the transition from the second characteristic different DAS. Change governance Watershed upstream of land such as reforestation, forest logging, deforestation, cultivation that ignores norms of conservation will have an impact on the end of the area, so DAS upper functions of protection in terms of governance of water [10].

\section{Result and Discussion}

\subsection{The institutional aspects of the management of the WATERSHED area of the Brantas}

One of the aspects of the good and the bad influence of rebellion in the management area is the institutional aspects of the ENGELS Brantas [2]. The findings of this research show that the institutional management of the WATERSHED area of the Brantas consists of the level of empowerment institution conservation and the level of empowerment of formal institutions on conservation. 
3.1.1 The level of institutional empowerment of communities to the conservation and preservation of the Watershed area of the Brantas (KWB).

In the area of DAS Brantas in principle, the community has learned about conservation nevertheless based on the conditions of the territory and in the region of DAS Brantas is divided into three (3) categories, among others:

1) On the fertile territory and production were greatly affecting a high economic value, conservation has been work in the community, including Kota Baru, Kec. Pujon Kec. Pacet and the surrounding District. Ngantang

2) On the less fertile areas and the soil is not too in which the production farm cannot sustain a lot of people's lives, this relic society understand conservation, but not many do and don't to do this, including the most upland, both located on the Upper part, the Brantas downstream area

3) In the area that is not very fertile withjeluk very thin soils where very low so that farm production is generally very unable to sustain the life of the Community/farmers then society is difficult to understand conservation and not doing conservation. In this area if no encouragement and the help of a good strong facilitation, mentoring and conservation treatment then there is no such zone of Cretaceous/ karst southern Brantas either in the Lava and Sub Sub DAS DAS Ngrowo-Ngasinan while in the North the mountain cluster in Brantas Kendeng Ciujung are on Sub Sub Widas, DAS DAS Bluwek DAS Maspo, and Sub.

The institutional community in stone town has assessed awareness within the conservation area of the WATERSHED. This breakfast buffet from a large number of public institutions is who pay attention to conservation and sustainability area DAS Brantas. Although institutional, community features stone town conservation and awareness to maintain the sustainability of the WATERSHED area of the Brantas. However, the public has a different perception towards conservation and sustainability area DAS Brantas. There are at least three different interconnected public perceptions:

1) Empirical Perceptions. The perception gleaned from everyday experiences of a long process. Seeing, feeling, repeatedly experiencing into a thing of fairness or, on the contrary, in a concise period of dramatic changes with significant impact. For example, among others, will experience a disaster will bring a realistic perception in drawing up the plan, confront and resolve the problem. Public participation is hard earned if program compiled by outside parties contrary to the empirical perception of society.

2) Public perception related directly to the community behavior. This perception shows the interrelationship between the problems of the community behavior. Direct linkages generally produce strong attempts to perform an action. Problems concerning his life society would be a low priority.

3) Public Perception Are Practical. Experience from the grasp of the environmental problems is more practical. Society community can fully implement the condition with little support required from outside parties. Technical and economic views are which more modest public perception will increase to a level that is getting better. The subjective approach based on the perception of the public with disabilities. 


\subsubsection{The level of empowerment of formal institutions for conservation and WATERSHED}

Area sustainability Brantas (KWB).

Formal Institutions on conservation in principle consist of an institution that was created in the form of forum DAS either Provincial or district level, National level and some districts, the two institutions/government agencies, among others, Department of Agriculture, Forestry, forestry, environment, Irrigation, Water Resources, Perhutani and Energy, Jasa Tirta, Forest Garden R. Soerjo, and Bromo Tengger Semeru National Park. If the contribution is reviewed against ecological conservation, the level of its role is very relative and depends on basic tasks and functions (Auth) respectively [11]. However, it can be found on most of the level of empowerment of formal institutions on conservation in the WATERSHED area are all very Brantas acted.

Unfortunately, the above formal institutions understanding in conservation and maintain the sustainability of the WATERSHED area is also different. Understanding different Rock City local government with the understanding of the Forestry Department, services for the water, and other institutions. This is caused by the difference in authority and the benefits obtained from the DAS Brantas. In the results of this research, the understanding of the Government of the city of Stone in this Department of agriculture, forestry, Gardening, environment, Irrigation and WATERSHED sustainability conservation against the very pragmatic, in which they give the opportunity to the community about to plant vegetables in areal DAS Brantas. On the other hand, the Forestry Department and service in order to emphasize the community around Tirta plant trees upright like coffee and guava trees in order to tackle soil erosion in the WATERSHED area of the Brantas.

Suradisastra, K [8], his research results reveal that the differences between the understanding of formal institutions in conservation activities and maintain the sustainability of the WATERSHED area of the Brantas is caused by the position of the authorities of the local government and other formal institutions. According to P, s. m., \& Suradisastra, K. local government is an institution as the center (core) where they have the Authority (government) in the form of the structure of leadership and decision-making processes. Other agencies have the authority but did not have the political power of the political power of the local government. That gap gives rise to disharmony the relationship between the nucleus and the Plasma in the institutional one [8].

\subsection{The role and Approach of conservation activities and Stakeholders Sustainability Area}

\section{DAS Brantas (KWB).}

The experience of Stakeholders in developing the integration of communications in the conduct of environmental services Activity facilitation FOCAL MESRA (Water and environmental Study Forum Towards Harmonised nature), Society of the village forest (LMDH), activities the National Partnership Movement Water Rescue Foundation (GNKPA) and the national movement of forest and land Rehabilitation (GNRHL) for the characterization of the area and diagnosis of WATERSHED issues the main and the problem associated with the functions of the DAS and behavior life (including source drinking water) has done well, though with a different approach. Focal Mesra through American participatory community in behavior life for repair with the analysis of the interconnectedness of the ecosystem of the forest, land cultivation, river/water source, and the settlement gives the information to draw up a comprehensive plan of action. Similarly the LMDH approach mapping in participatory and GN-KPA (micro-WATERSHED planning) and GN RHL-with a re-purposed Participatory 
Rapid Appraisal (pre). GIRAB adequate activity with the approach of the research through the activities of the river WATERSHED, but understanding the root of the problem of the existing issues has not been analyzed properly.

Assessment Of Land Use Landscape, slope, land use and zoning of vegetation, the ground of the Ridge up to the Valley of the River in Focal activities MESRA is done through participatory activities area of the village. LMDH activities conducted through participatory mapping in activities in their respective swaths of land the Forestry Department. Both activities have many utilize the scientific norms. While the GN-KPA (micro-WATERSHED planning) and GN-RHL is done through the efforts of a merger between the norms of scientific and public participation. The observation is done only GIRAB activities by the stakeholders. Understanding water flow and consequence flow laterally well done in GN-KPA (micro-WATERSHED planning) and GN RHL-through the analysis of estimated runoff surface, erosion model approach.

For Focal activities, MESRA is done with an inventory of local knowledge. For the activities of the Joint Community forest management (PHBM GIRAB) and is only done through observation a moment. The attribution of land use systems related to results, labor input requirements and production costs/benefits and impacts against the flow of water (impact on soil compaction, closure of land) performed well in the activities of the Focal field school and through Cordial GN-KPA (micro-WATERSHED planning) and GNRHL through the PRA approach.

For the activities of the PHBM and GIRAB was done through empirical understanding based on local experiences and promoted to strategic issues. Characterization of the mosaic landscape of land in view of the fragmentary - integrated, and consequence against bring together functions of production and environmental functions performed well in American Micro WATERSHED through land landscape mapping approach confirmed with in-depth interviews with the community. For the activities of the focal plane of blissful and PHBM did through empirical understanding based on informal discussions and stakeholder meetings and local experiences and was appointed to become the strategy focuses on the issue. To get the attention of less GIRAB activities.

Understanding the trade-offs between the functions of relative agronomist (RAF) and the relative environmental functions (REF), for example in the form of income adequacy of population per $\mathrm{km} 2$ as the RAF and the number of inhabitants with clean water sufficiency only got attention in the activity of LMDH to clarify for the results between LMDH, Perhutani and Stone City Government through incremental agreements, although the deal-understanding has not been well documented. Land landscape Mosaics in the context of water flow and "externalities" to making decisions on land farmers; the existence of rules and incentives (" carrots and sticks ${ }^{~}$ ) at the level of society and Government; moasik land landscape are there stable configuration to meet a need in the Focal activity led LMDH GIRAB and done well in agreements are participatory, making PERDES, raising support from other stakeholders. For the activities of the GN-KPA (micro-WATERSHED planning) and GNRHL is not yet clear the continuation of activities because these activities are designed based on projects by BBWS Times Brantas and BP DAS Brantas. Analysis of land use patterns and practices that exist based on the stakeholder perspective (including gender and equity) are quite well done in Focal activities Mesra and LMDH, but the issues raised have yet to clearly resolve the problem.

Understanding the existing problems and conflicts at the level of local knowledge, policies and scientific: as stages in negotiations conducted with Focal activities both in the Loveydovey, LMDH GIRAB through empirical approaches and experiences of long-term 
implemented by the local society are participatory but support substantive about understanding the function of a healthy WATERSHED is still biased. Understanding of Continuation of negotiations, followed by the monitoring activities and the impact of the service environment and community perpetrated by FOCAL MESRA and the continued existence of LMDH positive interactions in organic stakeholders. Watershed Planning for Micro to the present commitment of BBWS Times Brantas nor BP DAS Brantas to plan the effort made is unclear. For activities, GIRAB largely determined by the pioneering head of who, though he has been getting good support by the stakeholders in the area of the Sub, political intrigues flourish can interfere with the smooth running of the event.

\section{Conclusion}

Cooperation and coordination of stakeholders in the management of the area upstream WATERSHED Brantas are done through the strengthening of the institutional aspects of the management of the WATERSHED area of the Brantas. In this case, the community formed a number of institutions for conservation and maintain the sustainability of the area upstream WATERSHED Brantas. Unfortunately, the institutions of the community have formed a different understanding between them. Understanding of the people is grouped into three major parts, namely an understanding of pragmatic, normative understanding, and the understanding of conservation.

On the other hand, formal institutions such as local governments, Forestry Department, and services for the water also have a different understanding between them. The local government area of management looked at that DAS Brantas emphasized economic increased income have an impact on the community. Therefore, the Government is encouraging the public to utilize the WATERSHED area of the Brantas as area planting vegetables that cause soil erosion in the WATERSHED area. On the other hand, the Forestry Department and services encourage people to plant trees Tirta upright like coffee and guava as a ground erosion does not occur in the area of DAS. The difference in understanding the cause of cooperation and coordination between them cannot run effectively so that the management of the Watershed area of the Brantas is not maximal.

However, the civic and other formal institution still attempting to do conservation and maintain the sustainability of the WATERSHED area of the Brantas through various forms of approach, where all the existing approaches encourage people to get involved actively in conservation activities and maintain the sustainability of the WATERSHED area of the Brantas. Participatory approaches are considered effective approaches in WATERSHED conservation activities sustainable to embody the Brantas.

\section{References}

[1] A. Sham, "Dry land management system in the upper river basin," Agric. $R$ D J., vol. 22, no. 4, pp. 162-171, 2003.

[2] D. Faturohman, "The problem of management of Watersheds (DAS) Brantas in East Java," in a collaborative Model and Solution (Doctoral dissertation, Institute of Poor Farm), 2009.

[3] T. Sulistyaningsih, "Management model of open green space-based Democratization of public Role the actor in an effort to realize a Sustainable Town in Malang," in Competitive Grants Research Higher Education Phase II, 2010.

[4] T. Sulistyaningsih, S. Sulardi, and S. Sunarto, "Problems in the Upper Brantas 
Watershed Governance: A Case Study in Batu, Indonesia," Gov. Stud. J., vol. 8, no. 3, pp. 383-410, 2017.

[5] A. Herlambang, "Water pollution and penggulangannya strategies," Indones. Water J., vol. 2, no. 1, 2018.

[6] I. Mawardi, "Damage to watersheds and a decrease in water resources support power Java as well as handling efforts," Indones. Hidrosfir J., vol. 5, no. 2, 2011.

[7] R. Wirosoedarmo, A. T. Sutanhaji, and F. Zulfikar, "Analysis of land use Changes and its effects on pollution in Brantas Hulu, Batu, East Java. Journal of natural resources and environment," vol. 3, no. 1, pp. 33-39, 2018.

[8] K. Suradisastra, "Harmonization Of Institutional Management of The WATERSHED,” Cent. Econ. Policy Anal. Soisal Pertan. Bogor, 2012.

[9] B. Hartanto, "Prediction value of Erosion in the area Sub Das Brantas Micro Coban Talun," in study in the village of Tulungrejo sub-district of Talun Coban Bumiaji stone town (Doctoral dissertation, University of Muhammadiyah Malang), 2014.

[10] C. Asdak, Hydrology and watershed management. Yogjakarta: Gadjah Mada University Press, 2002.

[11] L. . Wibowo, "Public policy analysis of the development of the institutional Model of compensation Das Ciliwung (Public policy analysis on the development of a compensation model institution at Ciliwung Watershed)," he J. Hum. environme. 